included demographics, sexual behaviour, sex work characteristics and sexual healthcare and a 28-item STI knowledge scale (Jaworski and Carey, 2007). Adjusted prevalence ratios were estimated using poisson regression to assess the association between STI testing in the past year and standardised STI knowledge scores.

Results Participants were aged 18-55 years (Median: 28; IOR: 23-32), all born in Mexico and had been involved in sex trade a median of 6 years (IOR: 3-9). A majority (69\%) reported having an STI test in the past year and 39\% reporting three or more tests see Abstract P5-S7.15 table 1. Median STI knowledge score was $63 \%$ (IOR: $55-70)$. Notably, $43 \%$ and $33 \%$ did not think there were cures for Chlamydia and gonorrhoea, respectively. Among the 31\% with no STI test, $87 \%(\mathrm{~N}=95)$ indicated that this was because they "had been careful/always used condoms". However, of these, only $44 \%$ reported consistent condom use for vaginal sex with non-regular clients. In adjusted regression models accounting for education, income, years in sex work, number of clients and self-treatment, higher STI knowledge scores remained significantly associated with STI testing. Discussion STI knowledge was significantly associated with reporting STI testing in the past year. As women work in bars and brothels outside of the main entertainment district where the majority of FSW interventions are based, STI knowledge may have a greater impact on access and utilisation of testing services. Importantly, misperceptions regarding available treatment and perceptions of sexual risk were prevalent. Incorporation of sexual health education into existing HIV/STI programs is warranted and would be an efficient way to improve sexual healthcare in this population.

Abstract P5-S7.15 Table 1 Prevalence ratios for association of STI testing in past year with standardised STI knowledge score among FSW in Tijuana, Mexico

\begin{tabular}{|c|c|c|c|}
\hline & $\begin{array}{l}\text { STI test past } \\
\text { year, } N=277 \\
(69 \%)\end{array}$ & $\begin{array}{l}\text { No STI test past } \\
\text { year, } N=126 \\
(31 \%)\end{array}$ & $\begin{array}{l}\text { AdjPR } \\
(95 \% \mathrm{CI})\end{array}$ \\
\hline \multicolumn{4}{|l|}{ STI knowledge score } \\
\hline $\begin{array}{l}\text { Median } \% \text { of responses } \\
\text { correctly answered }\end{array}$ & $67(59-70)$ & $59(52-67)$ & - \\
\hline $\begin{array}{l}\text { Median standardised } \\
\text { score }\end{array}$ & $0.40(-0.38,0.79)$ & $-0.38(-1.16,0.40)$ & $1.10(1.03$ to 1.19$)$ \\
\hline Age $<25$ & $84(30 \%)$ & $40(32 \%)$ & - \\
\hline \multicolumn{4}{|l|}{ Work colonia } \\
\hline Region A & $131(47 \%)$ & $53(42 \%)$ & - \\
\hline Region $B$ & $146(53 \%)$ & $73(58 \%)$ & \\
\hline Lived in TJ whole life & $91(33 \%)$ & $36(29 \%)$ & - \\
\hline Education (>6 yrs) & $151(55 \%)$ & $55(44 \%)$ & 1.15 (1.01 to 1.30$)$ \\
\hline $\begin{array}{l}\text { Income (>3500 } \\
\text { pesos/mos) }\end{array}$ & $229(83 \%)$ & $56(44 \%)$ & 1.87 (1.51 to 2.32 ) \\
\hline Years of SW & $5(3,9)$ & $7.5(3,11)$ & $0.98(0.96$ to 0.99$)$ \\
\hline $10+$ clients/week & $158(57 \%)$ & $51(40 \%)$ & 1.20 (1.06 to 1.37 ) \\
\hline $\begin{array}{l}\text { Used Antibiotics for } \\
\text { STI w/out prescription } \\
\text { (ever) }\end{array}$ & $20(7 \%)$ & $26(21 \%)$ & $0.76(0.58$ to 0.99$)$ \\
\hline
\end{tabular}

Bold font indicates $p<0.05$.

\section{P5-S7.16 EASY ACCESS “COMMUNITY-BASED HIV TESTING SERVICES FOR GAY MEN: A SYSTEMATIC REVIEW"}

doi:10.1136/sextrans-2011-050108.611

${ }^{1}$ A Pedrana, ${ }^{1} \mathrm{M}$ Stoove, ${ }^{1} \mathrm{~A}$ Bowring, ${ }^{1} \mathrm{M}$ Hellard, ${ }^{2} \mathrm{R}$ Guy. ${ }^{1}$ Burnet Institute, Melbourne, Australia; ${ }^{2}$ National Centre in HIV Epidemiology and Clinical Research, Sydney, Australia

Background Community-based HIV testing has been widely utilised with the goal of increasing testing opportunities for gay men and decreasing the number of men who are unaware of their HIV status.
Abstract P5-S7.16 Table 1 Summary of community HIV testing services by setting and key outcomes of interest $(n=44)$

\begin{tabular}{|c|c|c|}
\hline Category & Subcategory & $\begin{array}{l}\text { All services } \\
\text { n (\%) }\end{array}$ \\
\hline \multirow[t]{8}{*}{ Location $(n=44)$} & Australia & $3(6.8)$ \\
\hline & Hong Kong & $1(2.3)$ \\
\hline & Spain & $1(2.3)$ \\
\hline & Switzerland & $1(2.3)$ \\
\hline & The Netherlands & $3(6.8)$ \\
\hline & New Zealand & $1(2.3)$ \\
\hline & UK & $6(13.6)$ \\
\hline & USA & $28(63.6)$ \\
\hline \multirow[t]{9}{*}{ Target group $(n=44) \dagger$} & Men who have sex with men (only) & $15(34.6)$ \\
\hline & Broader population including: & \\
\hline & MSM & $6(13.6)$ \\
\hline & Ethnic minority & $3(6.8)$ \\
\hline & Young people & $3(6.8)$ \\
\hline & Transgender & $3(6.8)$ \\
\hline & IDUs & $3(6.8)$ \\
\hline & Multiple & $11(25.0)$ \\
\hline & Not reported & $3(6.8)$ \\
\hline \multirow[t]{6}{*}{ Service type $(n=44)$} & On-site CВO & $8(18.2)$ \\
\hline & Community clinic* & $10(25.0)$ \\
\hline & Outreach Mobile testing facility (MTF) & $6(13.6)$ \\
\hline & Venue-based outreach (bar, club, sauna) & $8(18.2)$ \\
\hline & Multiple sites (venues, MTF, homeless shelter) & $5(11.4)$ \\
\hline & $\begin{array}{l}\text { On-site and outreach services (combination of } \\
\text { venues) }\end{array}$ & $7(15.9)$ \\
\hline \multirow[t]{4}{*}{ Number of sites $(n=44)$} & $1-2$ & $29(65.9)$ \\
\hline & $5-10$ & $2(4.6)$ \\
\hline & Multiple sites-number not reported & $12(27.3)$ \\
\hline & Not Specified & $1(2.3)$ \\
\hline \multirow{3}{*}{$\begin{array}{l}\text { Rapid HIV testing } \\
\text { offered }(n=44)\end{array}$} & Yes & $30(68.2)$ \\
\hline & Yes in parallel with conventional EIA testing & $4(9.1)$ \\
\hline & No & $10(22.7)$ \\
\hline \multirow{6}{*}{$\begin{array}{l}\text { Type of Rapid } \\
\text { Testing }(\mathrm{n}=28) \dagger \neq\end{array}$} & Abbott Determine HIV-1/2 rapid test & $12(42.9)$ \\
\hline & $\begin{array}{l}\text { Abbott-Murex Single Use Diagnostic } \\
\text { System for HIV-1 [SUDS] }\end{array}$ & $3(10.7)$ \\
\hline & Inverness Clearview HIV 1/2 STAT-PAK & $1(3.6)$ \\
\hline & OraSure OraQuick Advance Rapid HIV-1/2 Antibody & $12(42.9)$ \\
\hline & OraSure OraQuick Rapid HIV-1 Antibody & $10(35.7)$ \\
\hline & Unigold Recombigen HIV & $4(14.3)$ \\
\hline \multirow[t]{3}{*}{ Cost to patient $(n=32)$} & Nil - (covered by service/study) & $17(38.6)$ \\
\hline & Nil + incentive received for participating & $11(25.0)$ \\
\hline & $\$ 10-€ 20$ payment for test & $4(11.4)$ \\
\hline \multirow[t]{3}{*}{ Operating hours $(n=16)$} & $2-5 \mathrm{~h} /$ week & $10(62.5)$ \\
\hline & $5-10 \mathrm{~h} /$ week & $1(6.3)$ \\
\hline & $>10 \mathrm{~h} /$ week & $5(31.3)$ \\
\hline \multirow[t]{9}{*}{ Staff types $(n=26) \dagger$} & Administrative staff & $4(15.4)$ \\
\hline & HIV counselling \& testing staff/counsellors & $16(61.5)$ \\
\hline & Nurses/healthcare workers/clinic co-ordinator & $8(30.8)$ \\
\hline & Phlebotomists & $2(7.7)$ \\
\hline & Physicians/medical officers & $4(15.4)$ \\
\hline & Psychotherapists & $2(7.7)$ \\
\hline & $\begin{array}{l}\text { Sexual health educators/peer-workers/outreach } \\
\text { workers }\end{array}$ & $9(34.6)$ \\
\hline & Social workers/case managers & $2(7.7)$ \\
\hline & Volunteers & $4(15.4)$ \\
\hline \multirow[t]{3}{*}{ No Staff/shift $(n=19)$} & 1 & $1(5.3)$ \\
\hline & $2-3$ & $13(68.4)$ \\
\hline & $4-7$ & $5(26.3)$ \\
\hline
\end{tabular}

${ }^{*}$ Community clinics refer to services that offer direct medical services to clients; for example, STI/HIV testing and treatment, vaccinations, dental services and may have a licensed pharmacies or laboratory on-site.

†Target group, type of rapid test and staffing types are not mutually exclusive, so percentages do not add up to $100 \%$.

$\ddagger$ Some studies reported offering more than type of rapid test, therefore numbers do not add up to $\mathrm{n}=28$. 
Yet there remains ongoing debate as to whether such models offer advantages over routine clinical services. As such, there has been low uptake of community-based HIV testing in some countries. To better understand the processes and outcomes of these programs to inform future implementation, we systematically reviewed published studies.

Methods We searched Medline, EMBASE and Cochrane databases from 1980 to October 2010. Included studies described HIV testing outcomes of community based testing services that included gay men as clients. The primary outcomes were client testing history and HIV positivity.

Results We identified 33 papers that described 44 community-based HIV testing services. There were 18 on-site only services (community based organisations/community clinics, including one multi-fixed site), seven on-site services with outreach and 19 outreach only services, including eight outreach services in venues (bar, club, sauna); six mobile testing facilities and five community outreach sites in multiple locations (See Abstract P5-S7.16 table 1). The majority of the services were in the US (28 of 44) and 34 of 44 offered rapid HIV antibody testing on-site at the point-of-care. OraQuick Advance Rapid HIV-1/2 Antibody or Abbott Determine HIV-1/2 rapid with finger-stick were the most common tests used. Among services reporting testing outcomes specifically for gay men (22 of 44), the median proportion of men who had never tested for HIV prior to attending the community-based testing service was $34.1 \%$ (range: $7.8 \%-44.0 \%$ per service). The median HIV positivity was $3.9 \%$ (range: $0.3 \%-60.0 \%$ per service) and the median return rate for confirmatory testing was $83.8 \%$ (range: $22.7 \%-95.0 \%$ per service); higher in community-based organisation services $(84.2 \%)$ and lower in outreach models (33.0\%).

Conclusion Community-based HIV testing services provide a model of HIV testing that attracts a significant proportion of gay men who have never tested before, and these men are at high risk of HIV as evidenced by the HIV positivity rate.

\section{P5-S7.17 ACCEPTING THE GOOD WITH THE BAD: “BARRIERS AND FACILITATORS OF COMMUNITY-BASED HIV TESTING SERVICES FOR GAY MEN: A SYSTEMATIC REVIEW"}

doi:10.1136/sextrans-2011-050108.612

${ }^{1} \mathrm{~A}$ Pedrana, ${ }^{1} \mathrm{M}$ Stoove, ${ }^{1} \mathrm{~A}$ Bowring, ${ }^{1} \mathrm{M}$ Hellard, ${ }^{2} \mathrm{R}$ Guy. ${ }^{1}$ Burnet Institute, Melbourne, Australia; ${ }^{2}$ National Centre in HIV Epidemiology and Clinical Research Sydney Australia

Background With a global focus on increased HIV testing among high risk groups including men who have sex with men (MSM), many community-based HIV testing services have been established in recent years with the goal of increasing testing opportunities for populations at risk. To better understand the acceptability of community based HIV testing models targeting MSM from the provider and consumer perspective we systematically reviewed published studies.

Methods We searched Medline, EMBASE and Cochrane databases from 1980 to October 2010. Studies were included if they described acceptability of community based HIV testing services targeting MSM, including outreach settings (eg, saunas, public events), collected through surveys, in-depth interviews, focus groups, or exit forms. A quantitative descriptive analysis of the barriers and facilitators of community based HIV testing identified by service providers and consumers was conducted.

Results We identified 25 papers that met our selection criteria and were included in the review see Abstract P5-S7.17 table 1. Twenty one studies focused on facilitators from the consumers' perspective, with testing convenience, provision of rapid testing, and acceptability/feeling comfortable with settings reported at factors that facilitated seeking HIV testing at community based services. From the provider perspective (six studies) key factors enhancing service acceptability were client friendly protocols, service promotion, offering additional clinical services, and effective protocols for follow-up and referral. Sixteen studies captured barriers to using community based HIV testing services from the consumer perspective and the main issue reported related to readiness to receive results on the same day or in the community-based environment. Providers in six studies reported difficulties in followup, testing in outreach settings, cost, providing adequate staff training, managing workload and developing and maintaining referral pathways as key barriers.

Conclusion Acceptability from both consumers and service providers is important to ensure an efficient and sustainable service. The experiences of many other services collated in this review will help other organisations address potential barriers and facilitators to the implementation of community-based HIV testing services

Abstract P5-S7.17 Table 1 Summary of community HIV testing services (sample size) $(n=25)$

\begin{tabular}{|c|c|c|}
\hline Category & Subcategory & All services $\mathbf{n}(\%)$ \\
\hline \multirow[t]{7}{*}{ Location } & Canada & $1(4.0)$ \\
\hline & Hong Kong & $1(4.0)$ \\
\hline & New Zealand & $1(4.0)$ \\
\hline & Switzerland & $1(4.0)$ \\
\hline & The Netherlands & $3(12.0)$ \\
\hline & UK & $3(12.0)$ \\
\hline & USA & $15(60.0)$ \\
\hline \multirow[t]{3}{*}{ Target group } & MSM & $15(60.0)$ \\
\hline & Multiple & $7(28.0)$ \\
\hline & Unclear - CBO clients & $3(12.0)$ \\
\hline \multirow[t]{6}{*}{ Services type* } & $\mathrm{CBO} /$ community centre & $10(40.0)$ \\
\hline & STD clinic & $3(12.0)$ \\
\hline & Mobile testing facility & $1(4.0)$ \\
\hline & Needle exchange programs & $2(8.0)$ \\
\hline & $\begin{array}{l}\text { Venue-based outreach (bar, } \\
\text { club, sauna) }\end{array}$ & $9(36.0)$ \\
\hline & $\begin{array}{l}\text { Combination (eg, } \mathrm{CBO} \text {, outreach, } \\
\text { mobile testing facility). }\end{array}$ & $5(20.0)$ \\
\hline \multirow{4}{*}{$\begin{array}{l}\text { Rapid testing } \\
\text { offered }\end{array}$} & Yes & $13(52.0)$ \\
\hline & No & $5(20.0)$ \\
\hline & $\begin{array}{l}\text { Yes- in combination with } \\
\text { standard testing }\end{array}$ & $4(16.0)$ \\
\hline & Unclear & $3(12.0)$ \\
\hline \multirow[t]{7}{*}{ Study design } & Case studies & $1(4.0)$ \\
\hline & Clinical audit & $1(4.0)$ \\
\hline & Cross-sectional studies & $4(16.0)$ \\
\hline & Evaluation reports & $4(16.0)$ \\
\hline & Pilot/feasibility studies & $4(16.0)$ \\
\hline & Qualitative studies & $10(40.0)$ \\
\hline & Randomised trails (RCT) & $1(4.0)$ \\
\hline \multirow{5}{*}{$\begin{array}{l}\text { Data collection } \\
\text { methods* }\end{array}$} & Client surveys (including exit forms) & $15(60.0)$ \\
\hline & Focus groups & $2(8.0)$ \\
\hline & In-depth interviews & $5(20.0)$ \\
\hline & Provider surveys & $2(8.0)$ \\
\hline & Qualitative phone interviews & $3(12.0)$ \\
\hline \multirow[t]{3}{*}{ Study participants } & Clients & $17(68.0)$ \\
\hline & Providers & $4(16.0)$ \\
\hline & Clients \& providers & $4(16.0)$ \\
\hline
\end{tabular}

${ }^{*}$ Service types and data collection methods are not mutually exclusive, so \% do not add to $100 \%$ 